Article

\title{
Impacts of Leisure and Tourism on the Elderly's Quality of Life in Intimacy: A Comparative Study in Japan
}

\author{
Linghan Zhang and Junyi Zhang * \\ Mobilities and Urban Policy Lab, Graduate School for International Development and Cooperation, \\ Hiroshima University, Higashi Hiroshima 739-8529, Japan; maxzzlh@gmail.com \\ * Correspondence: zjy@hiroshima-u.ac.jp
}

Received: 16 November 2018; Accepted: 17 December 2018; Published: 19 December 2018

\begin{abstract}
Highly social activities like leisure and tourism are considered to have positive effects on the elderly's mental health. Taking Japan as a case study, this research aims to clarify how leisure and tourism contribute to the elderly's quality of life (QOL) in the domains of leisure and intimacy by comparing populated and depopulated areas. Such research has strong implications for achieving Sustainable Development Goals (SDGs) through healthy aging, but relevant efforts are quite limited. In this study, leisure and tourism behaviors are captured by visit frequency, travel party and expenditure. Quality of life is measured by happiness and life satisfaction in different life domains, in line with the life-oriented approach. Data were collected in 2014 via a nationwide online survey in Japan. Applying a structural equation model (SEM) approach, it is found that leisure behavior contributes to maintaining the elderly's QOL in leisure life and intimacy domains. Tourism behavior only contributes to QOL in populated areas. Leisure activities strongly enhance QOL in terms of intimacy and improve the neighborhood relationship of the elderly in depopulated areas and family life in populated areas. Enriching daily leisure activities for the elderly would improve their intimate relationships in depopulated areas.
\end{abstract}

Keywords: elderly; quality of life; happiness; life satisfaction; leisure behavior; tourism behavior; intimacy; depopulated areas; Japan

\section{Introduction}

Between 2015 and 2050, the ratio of people aged 60+ in the world will double [1]. Such an aging trend is especially remarkable in developed countries. Japan is the first country in the world to become a hyper-aged society (the elderly ratio (aged 65+) is larger than $21 \%$ ) and its current elderly ratio is $27.7 \%$ in 2017 [2]. Like many other developed countries, aging and depopulation in the peripheral areas have become the urgent social problems in Japan and particularly relevant for Sustainable Development Goals (SDGs) [1,3-5]. In this regard, elderly care has attracted public attention, especially in terms of health-related Quality of Life (QOL) and social care [6,7]. And there is a growing consensus that elderly care is not merely about maintaining the physical health of the elderly but also about maintaining their mental health [8]. In this context, research on QOL becomes relevant. Quality of life is often used as a set of comprehensive indicators to measure the current situations of people's lives. It is a dynamic interaction between the external conditions of an individual's life and the internal perception of those conditions $[9,10]$. Quality of life consists of multiple life domains, among which leisure, neighborhood and family life domains occupy most of elderly people's lives after retirement [11]. With discretionary time and disposable income, elderly people are more willing to participate in leisure 
and tourism activities [12], and elderly people's leisure life domain becomes the main conduit for social activities.

Leisure and tourism are highly social activities, which help to generate positive emotions and build social relationships [13]. The positive roles of leisure and tourism activities in improving QOL have been confirmed by many scholars (e.g., references [14,15]). Accordingly, literature has examined how tourism behavior and experience play important roles in affecting the overall QOL $[16,17]$ in the tourism industry, and how high involvement of leisure activities contributes to elderly people's QOL in the leisure industry $[18,19]$. Nevertheless, the effect of leisure and tourism on QOL has often been discussed separately. Little research has compared the contribution of elderly's leisure and tourism behaviors to their QOL jointly. Besides, existing studies focused on the positive role of leisure and tourism on the elderly people's overall QOL but neglected the multi-domains of QOL. Leisure and tourism activities are social activities that are highly connected with the elderly people's intimate relationships (family and neighborhood relationships). How leisure and tourism might affect different life domains of QOL is lacking insightful discussion. This study deals with QOL in leisure and intimacy life domains. Except for these research gaps, little can be found in literature about the elderly people's QOL in depopulated and disadvantaged areas [20]. Thousands of elderly people have been left to live solitary lives in neighborless communities, as relatives have migrated away or died, and nearby families have abandoned their homes [21]. Compared to elderly adults in cities, the elderly people in depopulated areas are easily being marginalized with less convenience for social activities. Their perception of QOL in leisure and intimacy life domains might differ from the elderly people in populated areas.

Therefore, this paper aims to understand the roles of leisure and tourism in improving the elderly people's QOL in leisure and intimacy life domains at the same time, by comparing depopulated and populated areas. A conceptual framework and hypotheses are built based on the literature of measuring the correlations between leisure, tourism and QOL in leisure and intimacy life domains. This study is an extension of previous studies on identifying the effect on QOL from not only tourism behavior but also daily leisure behavior, for having a continuum in tourism and daily leisure. In addition, it focuses on the effects of leisure and tourism activities on elderly intimate relationships, which may provide deeper insights on the improvement of the elderly's QOL and reveal various interactions in leisure, tourism and elderly people's social lives. The research questions are: (1) whether leisure and tourism have the same effect on the elderly's QOL in the domains of leisure and intimacy; (2) whether the elderly's leisure life can improve higher levels of QOL in intimate relationships; and (3) whether the relationships between leisure, tourism and QOL are all supported in depopulated and populated areas. A nationwide online survey was implemented in Japan to collect the elderly people's leisure and tourism behavior, and QOL in the domains of leisure and intimacy. A comparison between elderly persons in depopulated and populated areas is made to examine the commons and differences of the influential factors between leisure, tourism behavior and QOL. This study attempts to advance research on the continuum of leisure and tourism in relation to QOL by building a structural equation model. Tourism activities may not always enhance the elderly people's QOL when the impacts of leisure activities are considered simultaneously. The findings could be a supplement for not only the elderly tourism and leisure research but also the elderly's mental care research, in the context of depopulated (or disadvantaged) areas. What is more, the influence of QOL in the leisure life domain on the intimacy life domain is captured, which further reveals the mutual interactions between QOL in different life domains.

\section{Literature Review}

\subsection{Quality of Life (QOL) in Different Life Domains}

For a long time, the term QOL has been at the center of a lively debate and expanded in the context of various specialized areas such as sociology, psychology, medical and nursing science, economics, 
philosophy, history and geography [22]. Thus, the definitions of QOL are numerous and inconsistent within different subjects [23-25]. For instance, QOL could be defined as a person's sense of well-being, satisfaction or dissatisfaction with life, or happiness or unhappiness and even value $[20,26]$. Complex by its nature, QOL takes on different connotations that seem to proliferate endlessly. Hence, identifying some major strands of the measurement of QOL clarifies the theoretical outlines of this concept and empirical investigation.

\subsubsection{The Measurement of QOL}

It is confirmed by scholars that the measurement of QOL is based on different life conditions in various domains and the measurement has been broadened from materials goods to intangible evaluations $[27,28]$. Specific conceptualization and the increasing indicators have reflected such variations. For example, firstly the use of QOL referred to an "objective" index, such as economic growth, health and welfare in a social and psychological dimension [29-31]. Gradually the indicators of QOL were expanded to more "subjective" or positive concepts, and subjective well-being and psychology of happiness have spurred interest [32-34]. In the field of QOL study related to leisure and tourism, it was suggested that the measurement of QOL should combine both objective and subjective indicators. The objective indicators can be examined through criteria like frequency of leisure and tourism activities, number of travel companions and cost. On the other side, satisfaction and attitude in leisure and tourism activities could be subjective indicators [35,36]. Life satisfaction is the most-used indicator to measure each life domain of individuals, which measures the satisfaction with their basic life needs, leisure life, and overall life and so on [37]. Another direct indicator to measure leisure attitude is happiness, which has caught the interest of most contemporary authors who focus on the subject. Happiness is commonly used to assess how happy an individual is and to understand how much an individual likes his or her life [38], and it is used as a synonym of pleasure, utility, welfare or subjective well-being, which directly reveals his or her evaluation towards current life conditions [39-41]. Happiness is highly valued in the present society as an important measure of an individual's QOL [42,43]. Although happiness is an increasingly valued indicator of QOL and an invaluable personal goal pursued by all individuals, few studies on tourism or leisure have used it as a direct evaluation to explain QOL. With the above review, the measurement of QOL was divided into two main parts in this study: Life satisfaction and happiness, because they represent different aspects of QOL.

\subsubsection{Quality of Life in Leisure and Intimacy Life Domains}

An individual's QOL ranges from psychical needs to mental fulfillments. Quality of life in leisure life refers to an individual's satisfaction and happiness with his/her person-centered leisure engagement, which could be leisure participation, tourism frequency, etc. [36]. Similarly, QOL in the intimacy domain (hereafter, called QOL in intimacy) refers to an individual's satisfaction and happiness with their non-sexual intimate relationships (e.g., close relationship with family, friends, marriage and partnerships). Based on the life-oriented approach [11], Zhang and Xiong [44] examined how various life domains (e.g., residence, neighborhood, health, education, work, family life, leisure and recreation, finance and travel behavior) affected Japanese people's happiness as a whole and in different domains. Among all the domains under study, neighborhood, work and family life domains are the ones with active social interactions and intimate relationships with others. As our target respondents are the elderly, most of whom are retired, the domain of work is excluded. In this study, QOL in intimacy among elders refers to individual satisfaction and happiness in their family and neighborhood life domains.

Although the possible number of life domains is large, and different life domains seem not to be independent of each other, the ordering of dependencies across various life domains is debatable. Cummins [30] attempted to identify and group different life domains under seven QOL scales (material well-being, health, productivity, intimacy, safety, community, emotional well-being). Among the 
different life domains, $85 \%$ of life domains included emotional well-being in the form of leisure, subjective well-being, morale, etc., and $70 \%$ included social and family connections (intimacy). He further found that the domain of intimacy received a higher rate of satisfaction than all other domains. The domination of QOL in intimacy affecting elderly people's lives should be further discussed. In the study of leisure, tourism and QOL, a bottom-up spillover theory was often applied to decide the relationships between life satisfaction in leisure and tourism, and overall life satisfaction $[45,46]$. The fundamental concept of bottom-up spillover theory is that satisfaction with all life subdomains, such as social life, material well-being, leisure life and work life, would influence an individual's overall life satisfaction [47,48]. The QOL in leisure life is not only the achievable goal of individuals but also the mediate factor in influencing QOL in other life domains. Social interaction is a central component of leisure and tourism activities [49], and it is believed that leisure and tourist activities would increase an individual's QOL in leisure life and further enhance QOL in other life domains, especially in intimate relationships.

\subsection{Leisure, Tourism and QOL of the Elderly}

Leisure and tourism studies have been historically discussed in isolation from their roles in QOL. However, considering a wider range of QOL in leisure life domain, leisure studies offer a number of intriguing parallels with tourism [50], and tourism should be added at the end of a broad leisure spectrum [51,52]. As claimed by Carr [53], there exists a "tourism-leisure continuum", and the factors of individual personal characteristics, motivations and physical environment somehow decide the correlation between tourist and leisure behaviors. Tourism and leisure should be considered jointly for their impact on an individual's QOL.

For a long time, leisure-related variables are reported to have had a positive influence on individual QOL, especially on the subjective feelings in QOL [54,55]. Mishra [56] found a positive correlation between high QOL and an individual's involvement in the activities connected with occupation, hobbies and interactions with the friends and members of voluntary organizations. Daily leisure activities are often performed within the context of social relationships that may provide health-enhancing benefits [57]. Leisure activities were found to increase emotional well-being and life satisfaction among adults $[13,58,59]$. Tourism and individual QOL have also become popular topics in recent years, and most studies agreed that tourism, especially vacation experience, has a positive effect on QOL [22,60-62]. Moreover, some scholars further pointed out that tourism is an enhancement factor for QOL instead of a dominant one $[48,63]$.

Existing studies on leisure-tourism behaviors in elderly people's QOL are quite limited. Lee and Tideswell [64] found that vacation travel improved QOL for senior citizens and created new interests in their lives. Arslantas et al. [65] analyzed QOL and activities of daily living of elderly people in rural areas of Eskisehir. The results showed that daily life activities would deteriorate as people got older, and thus, medical-social services should be prioritized and reevaluated. Fassino et al. [66] studied the QOL of independent older adults who stayed at home and advocated more articulated and multidisciplinary geriatric and psychosocial interventions in this population. Woo et al. [67] analyzed the relationship between travel behavior and QOL.

For the elderly, both daily leisure and tourism activities are important components of their discretionary time. Existing studies have separated the roles of leisure and tourism in explaining an individual's QOL. It is still unclear that whether leisure and tourism could have the same positive effect on the elderly's QOL when they were compared together. In addition, although QOL is a concept that is widely used in gerontology and senior tourism marketing in megaregions [68,69], only a small number of studies discussed the QOL of the elderly in peripheral areas.

\subsection{Related Studies in Japan}

The relevant studies in Japan often focus on the elderly's physical health conditions instead of the subjective perception of QOL. For example, leisure activities can reduce the risk of dementia 
or postpone the cognitive decline of the elderly [70,71]. The social role of leisure and tourism in maintaining the elderly's QOL has been neglected in the context of Japan, let alone the depopulated areas. There were a few studies regarding elderly tourism activities in Japan, but only about profiling or explaining senior tourists' characteristics, and tourist motivations for the purpose of better tourism marketing [72,73]. However, whether tourism would enhance the elderly's QOL mentally is still unknown. As leisure and tourism activities took up most of the elderly people's time in their later years, the effects of leisure and tourism on the elderly's QOL should be better discussed regarding the form of leisure and intimate relationships.

\section{Methodologies}

\subsection{Conceptural Framework}

The main structure of this research was principally operationalized using the scales found in the existing literature. Hypotheses were established based on the correlation and hierarchy of different life domains in QOL [11,30]. The framework is shown in Figure 1.

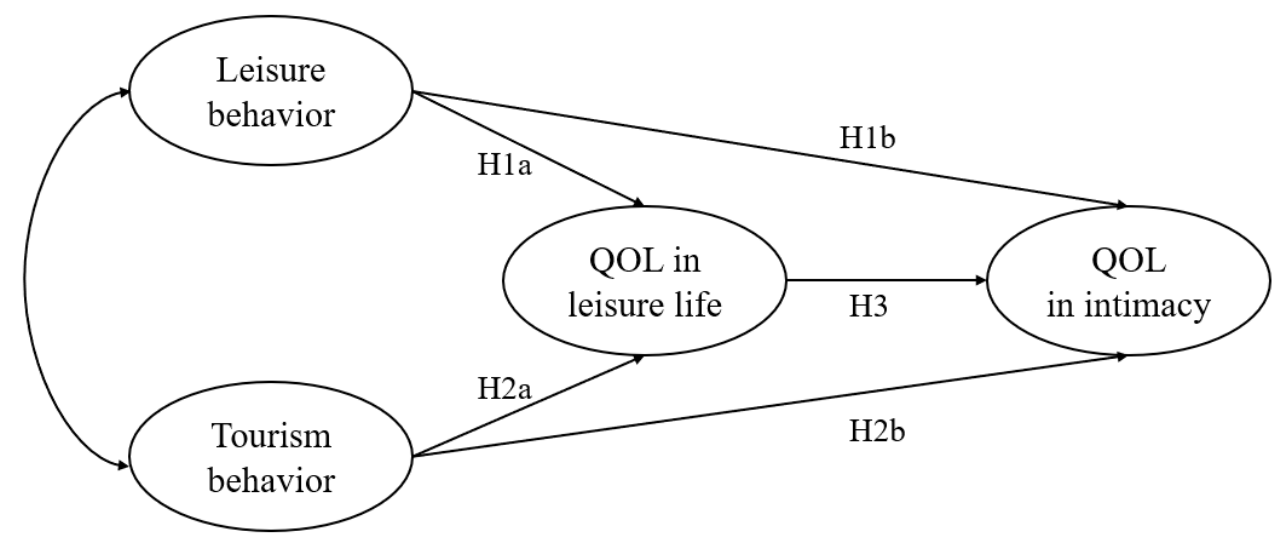

Figure 1. The relationships between leisure-tourism behavior and quality of life (QOL).

Quality of life is composed of discrete domains, for instance, material well-being, health, work, community, intimacy and safety. The range of life domains in QOL is extended with individuals' understanding and evaluation of QOL. If each term describing an individual's life conditions is regarded as a separate life domain, then the number of domains would become countless. Fortunately, many life aspects of QOL share a great deal of their meanings and scope. Moreover, in both theoretical and empirical studies of different life domains of QOL, the hierarchy of life domain is measured to explain what life domains are important to an individual and how they are correlated with each other [74,75]. However, in most studies on the impact of leisure and tourism on elderly people's QOL, only overall QOL was measured, rather than the hierarchy of QOL domains. Such hierarchy may reflect different priorities of life domains in people's life choices. The life domain of intimacy was found to be dominant among other life domains [30,76], which is closely related to elderly people's later social life and mental health. Thus, in this study, QOL in intimacy was chosen as the first targeted variable. Leisure and tourism activities consist of highly socialized activities and are proved to have positive effects on individual QOL. More frequent participation in leisure and tourism activities is related to a higher level of satisfaction and happiness [54,77]. In addition, travel party could be another important factor in leisure and tourism activities to influence elderly people's QOL, especially in respect of intimate relationships. The engagement in leisure and tourism activities not only keeps pleasant life conditions for the elderly but also improves health conditions and reduces the risk of mortality in later life [78]. Having a happy leisure life could be a survival advantage among the elderly in their physical, emotional and mental lives [57], which would enhance intimacy with others. 
The hypotheses in this study are established based on the literature review and our own arguments, where it is assumed that leisure and tourism behaviors would have different effects on QOL among elderly people in different regions. The hypotheses also represent the main research questions in this study, including whether leisure and tourism have the same effect on the QOL of the elderly, whether the relationships are all supported in both depopulated and populated areas, and whether elderly people's leisure life can provide higher levels of QOL in intimacy.

Hypothesis 1a. Leisure behavior would contribute to elderly people's QOL in leisure life in both depopulated and populated areas.

Hypothesis $\mathbf{1 b}$. Leisure behavior would contribute to elderly people's QOL in intimacy in both depopulated and populated areas.

Hypothesis 2a. Tourism behavior would contribute to elderly people's QOL in leisure life in both depopulated and populated areas.

Hypothesis $\mathbf{2 b}$. Tourism behavior would contribute to elderly people's QOL in intimacy in both depopulated and populated areas.

Hypothesis 3. Quality of life in leisure life would have positive effects on QOL in intimacy among the elderly in both depopulated and populated areas.

Leisure preference items reveal the basic needs and current situations of elderly people and contain elderly people's social relationship with others [56,57]. The latent variable "tourism behavior" is defined in terms of tourism frequencies, travel parties, and tourism expenditure in overseas and domestic travel. Similarly, "leisure behavior" is a latent variable that captures leisure frequencies, leisure parties and leisure cost. For a comprehensive understanding of QOL and behavioral independencies among life choices, Zhang [11] proposed the life-oriented approach, which can measure life satisfaction and happiness as a whole and in different life domains in a systematic way. This study focuses on elderly people's QOL in their leisure life and its influence on their intimacy. Thus, only QOL in leisure life, family life and neighborhood life domains was used here. For life satisfaction, a five-point Likert-type scale that ranges from "highly dissatisfied" (1) to "highly satisfied" (5) was used. Happiness as a whole was measured on a 10-point scale (0: very unhappy, $\ldots, 10$ : very happy) by asking the question, "How happy are you feeling currently?". Happiness at the domain level was measured based on the concept of affective experience $[48,79,80]$. The percentages of time during which a respondent reported being in specific moods were recorded: Bad, low or irritable, mildly pleasant, or very good mood. These percentages had to add up to $100 \%$ for each life domain.

\subsection{Structural Equation Model}

The main aims of this study of data analysis are (1) to build an integrated model of the elderly people's QOL in leisure and intimacy by examining the correlations between leisure and tourism behaviors, and (2) to make a comparison between depopulated and populated areas, in the context of Japan. To this end, structural equation modeling (SEM) with latent variables was applied, which is composed of structural and measurement equations [81-83]. Structural equations illustrate the relationships between latent variables, and measurement equations describe whether and how much each latent variable can be used to explain observed variables.

Structural equation model

$$
\eta=\mathrm{B} \eta+\Gamma \xi+\zeta
$$


Measurement model for endogenous observed variable $y$

$$
y=\Lambda_{y} \eta+\varepsilon
$$

Measurement model for exogenous observed variable $x$

$$
x=\Lambda_{x} \xi+\delta
$$

Here, $\eta^{\prime}=\left(\eta_{1}, \eta_{2}, \ldots, \eta_{m}\right)$ and $\xi^{\prime}=\left(\xi_{1}, \xi_{2}, \ldots, \xi_{m}\right)$ are latent endogenous and exogenous variables, which are not observed. And, $y^{\prime}=\left(y_{1}, y_{2}, \ldots, y_{p}\right)$ and $x^{\prime}=\left(x_{1}, x_{2}, \ldots, x_{q}\right)$ are the observed dependent and independent variables, respectively, $\zeta, \varepsilon, \delta$ are the vectors of error terms, and $\mathrm{B}, \Gamma, \Lambda_{x}, \Lambda_{y}$ are the vectors of unknown parameters. Latent variables are variables that are inferred from observed variables.

Tourism research started to use SEM over the last decade [84,85], especially in studies measuring different tourism stakeholders' attitudes towards the development of tourism [86]. For example, Gursoy et al. [87] combined community concern, attachment, utilization of tourism resources and the perception of perceived benefits by residents using SEM. Mishra [56] applied SEM to estimate retirees' engagement in various activities and their life satisfaction, and Gross and Brown [88] conducted an empirical study of the relationship between involvement and place attachment in the tourism process. Structural equation modeling is useful for examining the interrelationships among various constructs simultaneously [89].

\subsection{Questionnaire Design and Data Collection}

For this study, data were extracted from a web-based life-choices and QOL survey, including various life aspects, which was implemented in major Japanese cities in 2014. The structured questionnaire aimed to capture the general picture of Japanese people's daily lives. Both objective and subjective questions were included. In the objective questions, respondents' residential behavior, travel behavior, family life, health, neighborhood communication, expenditures, energy consumption, daily leisure activities, tourism activities, individual and household attributes and so on were investigated. And for the subjective questions, respondents' evaluations about life satisfaction and happiness were mainly reported. The survey was implemented with the assistance of a major Japanese internet survey company, which had more than 1.4 million registered survey panels at the time the survey was conducted. Respondents from the whole of Japan were randomly selected, by considering the age, gender and region distributions of the population, from which more elderly samples were collected because of the focus of this study. As a result, 1114 respondents aged above 18 years old participated in the survey, among which, $66.6 \%$ of all the respondents were aged from 65 to 99 years old; these were the final samples used in this study. In this data set, 297 elderly people (aged 65 or more) were from depopulated areas and 466 elderly people were from populated areas. The Ministry of Internal Affairs and Communications, Japan defines a depopulated area mainly based on the share of elderly people. Currently, $47.6 \%$ of cities, towns and villages in Japan are classified as depopulated areas, where the population share is $8.6 \%$ and the area share is $59.7 \%$ in 2017 [90]. For this study, questions about daily leisure activities and tourism, life satisfaction and happiness were mainly used.

As shown in Table 1, in both areas, more male elderly respondents answered the survey. Most of the respondents were aged between 65 and 85 . Due to the use of internet survey, more "young senior" (just over age 65 and under 75 ) participated in this survey. Overall, $52.1 \%$ of the elderly participants had a job in a depopulated area; however, from the work category, most of them were self-employed, doing a farming job on their own land instead of any formal occupation. For number of children, elderly people in depopulated areas had a bigger number, on average. The income in populated areas was higher than in depopulated areas. Comparing the overall scores of happiness and life satisfaction in both areas, the differences were minor, but elderly people in populated areas seemed to be more satisfied with their current life situations. Obviously, the leisure and domestic tourism activities in 
depopulated areas were more frequent than those in populated areas. In contrast, the overseas tourism frequency did not show a significant difference between the two areas.

Table 1. Socio-demographics of the elderly in depopulated and populated areas.

\begin{tabular}{|c|c|c|c|}
\hline \multicolumn{2}{|c|}{ Individual Attributes } & \multirow{2}{*}{$\begin{array}{c}\text { Depopulated Areas } \\
76.4 \%\end{array}$} & \multirow{2}{*}{$\begin{array}{c}\text { Populated Areas } \\
59 \%\end{array}$} \\
\hline $\operatorname{sex}$ & Male & & \\
\hline & Female & $23.6 \%$ & $41 \%$ \\
\hline \multirow[t]{3}{*}{ Age (years) } & $65-75$ & $88.9 \%$ & $84.3 \%$ \\
\hline & $76-85$ & $11.1 \%$ & $14.8 \%$ \\
\hline & $>85$ & $0 \%$ & $0.9 \%$ \\
\hline Occupation & Have a job & $52.1 \%$ & $46.9 \%$ \\
\hline Marital status & Married & $85.5 \%$ & $68.9 \%$ \\
\hline \multicolumn{2}{|c|}{ Number of children } & 1.74 & 1.49 \\
\hline \multicolumn{2}{|c|}{ Individual income (JPY/year) } & 362,700 & 418,700 \\
\hline \multicolumn{2}{|c|}{ Score of overall happiness } & 7.86 & 7.84 \\
\hline \multicolumn{2}{|c|}{ Score of overall life satisfaction } & 3.69 & 3.75 \\
\hline \multicolumn{2}{|c|}{ Daily leisure frequency } & 5.39 & 4.39 \\
\hline \multicolumn{2}{|c|}{ Domestic tourism frequency } & 3.35 & 2.82 \\
\hline \multicolumn{2}{|c|}{ Overseas tourism frequency } & 0.31 & 0.33 \\
\hline \multicolumn{2}{|c|}{ Sample size (persons) } & 297 & 466 \\
\hline
\end{tabular}

\subsection{Ethical and Legal Considerations}

This research was financially supported by two scientific projects of Grants-in-Aid for Scientific Research (A), Japan Society for the Promotion of Science (JSPS) (Funding IDs: 15H02271 \& 22246068). The survey was approved by Hiroshima University, Japan and conducted with the direct consent of each respondent.

\section{Estimated Results}

\subsection{Findings of the SEM Analysis}

Here, AMOS Version 22 software was used to estimate the SEM for this study and analyzed/compared two data sets: One from depopulated areas (sample size: 297 persons) and the other from populated areas (sample size: 466 persons). For treating non-normal data like dummy variables in our data set, a bootstrap method was applied to estimate SEM models. The bootstrap method is a resampling method to create a sampling distribution to estimate standard errors and to create the confidence levels. Here, the number of bootstrap samples was set to be 200 and percentile confidence intervals to be $90 \%$ and bias-corrected confidence intervals to be $90 \%$. The converged results obtained successfully. Model accuracy indicators and parameter values suggest that the assumed model structures are acceptable. In the case of depopulated areas, GFI $=0.81$ and AGFI $=0.75$, while, in the case of the populated areas, GFI $=0.82$ and AGFI $=0.75$. Most of the observed variables in both models are statistically significant at the $5 \%$ or $1 \%$ level. Model estimation results of SEM for depopulated and populated areas are shown in Figures 2 and 3, Tables 2 and 3, respectively.

From Figure 2 and Table 2, it is confirmed that Hypotheses 1 and 3 are supported while Hypothesis 2 is rejected. Leisure activities play an important role in enhancing elderly people's QOL in leisure life, and indirectly increasing their QOL in intimacy. On the other hand, tourism activities do not have any effect (either direct, indirect or total effect) on the elderly people's QOL in leisure life or intimacy. Also, the perception of high QOL in leisure life has a positive effect on QOL in intimacy among the elderly in depopulated areas.

The results in populated areas (Figure 3 and Table 3) are similar to those in depopulated areas in terms of Hypotheses 1 and 3. Furthermore, Hypothesis 2 is supported in the populated areas. Both leisure and tourism behaviors have a direct positive effect on elderly people's QOL in leisure life and have an indirect positive effect on their QOL in intimacy. As shown by the standardized total 
effects (Table 3), the effect of leisure (0.384) is bigger than tourism behavior (0.135), and the elderly people's QOL in leisure life strongly affects their QOL in intimacy in populated areas, because its total effect is 0.893 , which is larger than any other variables.

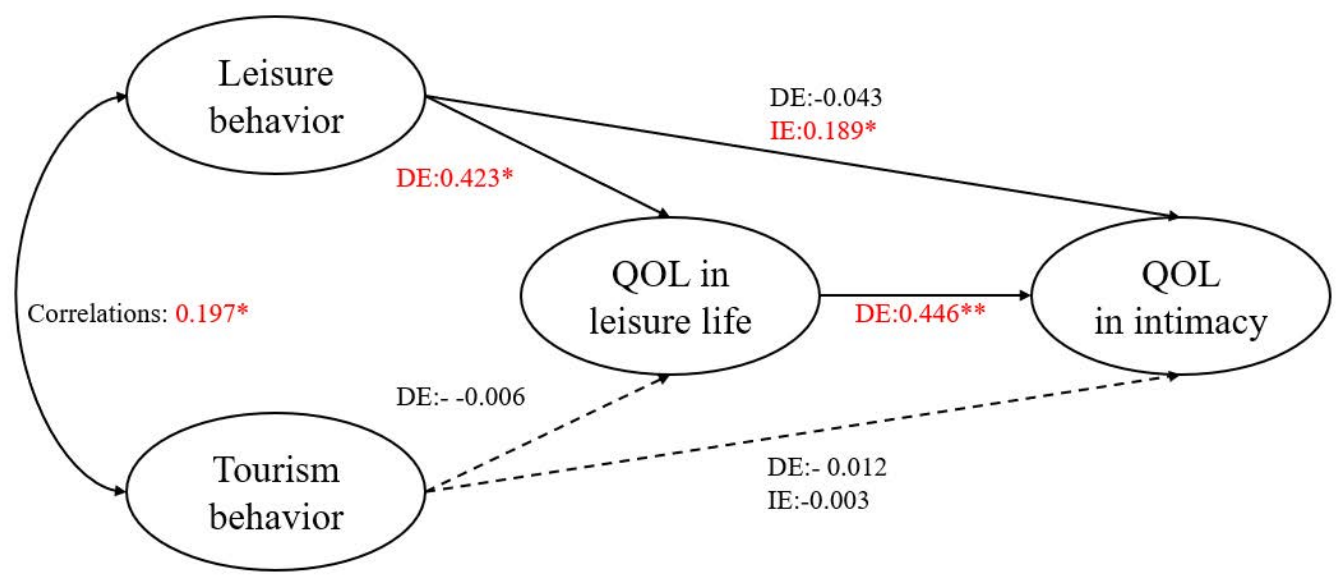

Figure 2. The direct and indirect effects of SEM results in depopulated areas.

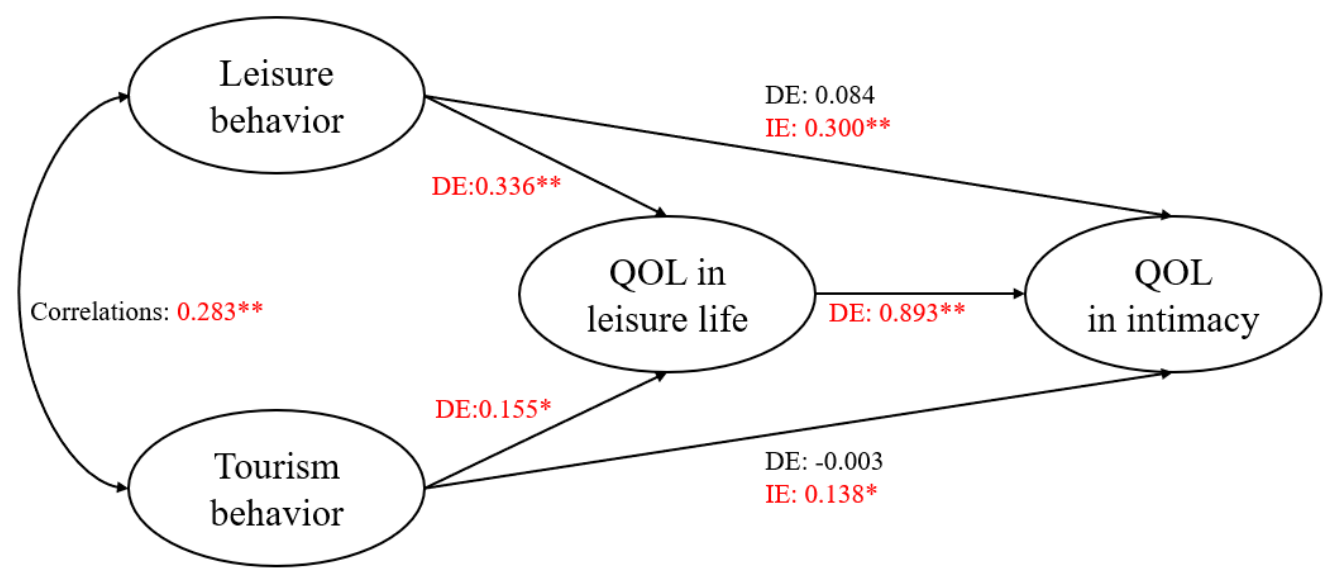

GFI $=0.82$; AGFI $=0.75$; Sample size $=466 ;{ }^{*}$ : Significant at $5 \%$ level; ${ }^{* *}$ : Significant at $1 \%$ level; DE: Direct Effect; IE: Indirect Effect.

Figure 3. The direct and indirect effects of SEM results in populated areas.

Table 2. The standardized total effects of SEM results in depopulated areas.

\begin{tabular}{cccc}
\hline Enogenous Variables & Leisure Behavior & Tourism Behavior & QOL in Leisure Life \\
\hline QOL in leisure life & $0.423^{*}$ & -0.006 & \multirow{2}{*}{$0.446^{* *}$} \\
QOL in intimacy & 0.146 & 0.010 &
\end{tabular}

*: Significant at $5 \%$ level; **: Significant at $1 \%$ level.

Table 3. The standardized total effects of SEM results in populated areas.

\begin{tabular}{cccc}
\hline Enogenous Variables & Leisure Behavior & Tourism Behavior & QOL in Leisure Life \\
\hline QOL in leisure life & $0.336^{* *}$ & $0.155^{*}$ & $0.893^{* *}$ \\
\hline QOL in intimacy & $0.384^{* *}$ & $0.135^{*}$ & 0.000 \\
\hline
\end{tabular}

*: Significant at $5 \%$ level; **: Significant at $1 \%$ level. 


\subsection{Comparison of Results between Depopulated and Populated Areas}

As shown in Table 4, in the depopulated areas, leisure behavior is mostly captured by leisure frequency because its standardized parameter is 0.581 , which is the highest among three observed leisure behavior variables. All the observed variables related to overseas tourism experience have high values among tourism behavior variables, indicating that they mainly represent tourism behavior, whereas, in populated areas, travel party in leisure and in overseas tourism is the most important factor to capture leisure and tourism behaviors. Compared to domestic tourism, overseas tourism is much more concerned among the elderly in populated areas because the parameters of overseas tourism related variables (0.722-0.861) are much larger than those of domestic tourism variables $(0.257-0.267)$. As for QOL in leisure life, life satisfaction in leisure has the highest parameter value: 0.726 and 0.802 in depopulated and populated areas, respectively. However, concerning QOL in intimacy, there is a huge difference among observed variables. Observed variables related to neighborhood relationships are highly concerned among the elderly in depopulated areas; however, in populated areas, the situations are totally opposite: Observed variables related to family life play a dominant role in representing QOL in intimacy.

Table 4. Factors affecting the elderly's QOL in depopulated and populated areas.

\begin{tabular}{|c|c|c|c|}
\hline \multicolumn{2}{|l|}{ Depopulated Areas } & \multicolumn{2}{|l|}{ Populated Areas } \\
\hline Variables & Parameter & Variables & Parameter \\
\hline Leisure behavior & & Leisure behavior & \\
\hline Leisure frequency & $0.581^{* * *}$ & Travel party in leisure activities & $0.666^{* * *}$ \\
\hline Travel party in leisure activities & $0.501^{* * *}$ & Leisure frequency & $0.427^{* * *}$ \\
\hline Average cost of leisure activities per day & 0.458 & Average cost of leisure activities per day & 0.422 \\
\hline Tourism behavior & & Tourism behavior & \\
\hline Cost in overseas tourism per time & $0.869 * * *$ & Travel party in overseas tourism & $0.861 * * *$ \\
\hline Travel party in overseas tourism & $0.840 * * *$ & Cost in overseas tourism per time & $0.811^{* * *}$ \\
\hline Overseas tourism frequency & 0.616 & Overseas tourism frequency & 0.722 \\
\hline Travel party in domestic tourism & $0.179^{* * *}$ & Cost in domestic tourism per time & $0.267^{* * *}$ \\
\hline Cost in domestic tourism per time & 0.116 * & Travel party in domestic tourism & $0.266 * * *$ \\
\hline Domestic tourism frequency & $0.113 *$ & Domestic tourism frequency & $0.257 * * *$ \\
\hline QOL in leisure life & & QOL in leisure life & \\
\hline Life satisfaction in leisure life & $0.726^{* * *}$ & Life satisfaction in leisure life & $0.802 * * *$ \\
\hline Preference degree in leisure life & 0.397 & Good and mild pleasant in leisure life & 0.457 \\
\hline Good and mild pleasant in leisure life & $0.249^{* * *}$ & Preference degree in leisure life & $0.157 * * *$ \\
\hline QOL in intimacy & & QOL in intimacy & \\
\hline Preference degree in neighborhood & 0.814 & Life satisfaction in family life & $0.798^{* * *}$ \\
\hline $\begin{array}{l}\text { Feel happy/mild pleasant in } \\
\text { neighborhood }\end{array}$ & $0.800 * * *$ & Feel happy/mild pleasant in family life & $0.550^{* * *}$ \\
\hline Life satisfaction in neighborhood & $0.551 * * *$ & Life satisfaction in neighborhood & $0.407^{* * *}$ \\
\hline Feel happy/mild pleasant in family life & $0.386^{* * *}$ & Feel happy/mild pleasant in neighborhood & $0.239 * * *$ \\
\hline Life satisfaction in family life & $0.378 * * *$ & Preference degree in neighborhood & 0.192 \\
\hline
\end{tabular}

${ }^{*}$ : Significant at $10 \%$ level; ${ }^{* * *}$ : Significant at $1 \%$ level.

The similarities and differences between depopulated and populated areas are summarized below. Similarities:

(1) Leisure behavior directly contributes to maintaining QOL in leisure life and indirectly contributes to maintaining QOL in intimacy among elderly people in both depopulated and populated areas (Hypothesis 1 is supported).

(2) Elderly people's QOL in intimacy is directly affected by QOL in leisure life in both depopulated and populated areas (Hypothesis 3 is supported).

(3) Overseas experience is highly valued in tourism behavior in both depopulated and populated areas. 


\section{Differences:}

(1) Tourism behavior contributes to maintaining QOL in leisure life and indirectly influences QOL in intimacy among the elderly people in populated areas (Hypothesis 2 is supported only in populated areas).

(2) Travel parties in leisure and tourism activities are considered more by the elderly in populated areas while leisure frequency is more important to elders in depopulated areas.

(3) Neighborhood relationships are more important than family life in QOL in intimacy in depopulated areas. Whereas, in the populated areas, the result is totally opposite: Family life is valued higher in QOL in intimacy.

Leisure and tourism activities jointly contribute to elderly people's QOL, and they are significantly correlated with each other. The different findings from the depopulated areas provide an important warning message against tourism development for the elderly in depopulated areas. This advances the leisure and tourism research, because the results show that tourism is not always an enhancement for elderly people's QOL. The different patterns and concerns of QOL between the elderly people in depopulated and populated areas call for various policy strategies of elderly care in order to achieve the Sustainable Development Goals.

\section{Discussion}

\subsection{The Importance of Leisure Activities among Elderly People in Both Depopulated and Populated Areas}

Leisure plays an important role in keeping elderly people's QOL in leisure life and QOL in intimacy among elderly people in both depopulated and populated areas. Compared to tourism activities, which are often an annual or even less frequent experience for the elderly in depopulated areas, leisure activities seem to be more attainable and accessible. Leisure activities within the context of friendship, kinship and organizational participation are the key components in promoting health and sense of happiness among the elderly [91]. Thus, it can directly influence elderly people's QOL in leisure life and further influence QOL in intimacy in both areas. Even visiting and talking to friends or neighbors may reduce their risk of mortality and enhance life satisfaction and happiness [92]. For the effects on QOL in intimacy, the connection between friends and neighbors in depopulated areas (small towns and villages) is closer than in populated areas; neighbors are more familiar with each other compared to the elderly living in large cities, which may explain why the neighborhood domain is more important in QOL in intimacy.

However, for the elderly in populated areas, it is found that partners in leisure activities are important and family life mainly decided QOL in intimacy. When the elderly have companionship, they feel positive emotion, social and cultural connection and a harmony through daily leisure [93]. Leisure activities comprise "maintaining close relationships" and "remaining involved in activities that are meaningful and purposeful" to provide social and leisure involvement for aged persons [78]. Leisure activities and tourism activities could be an effective way for the elderly to make interactions with family, friends and neighbors, and it could create a sense of attachment in daily life and help to maintain better health and higher QOL in intimacy [94].

\subsection{The Enhancement Role of Tourism among the Elderly in Populated Areas}

Do the elderly really need tourism to enhance their QOL in depopulated areas? If only considering the popularity of senior tourism, the answer is obviously yes, and tourism is necessary for the later life of the elderly. Nevertheless, in our findings, tourism activities did not have positive effects on the elderly people's QOL in leisure life and intimacy in depopulated areas. However, tourism contributed to the QOL of the elderly in populated areas. Previous studies proved that tourism is an enhancement of QOL for elderly [95] but did not point out the potential differences in the elderly in different regions. Our findings in depopulated areas made a supplementary contribution to understanding the 
relationships between tourism and QOL in depopulated areas. Tourism is not the first choice for the elderly living in depopulated areas. Both academia and policymakers should pay more attention to the differences of the elderly in depopulated and populated areas.

The findings of this study supported the significant influence of leisure and tourism on the QOL of the elderly and further revealed the similarities and differences between the elderly in depopulated and populated areas. In addition, the model results were supported, while there was a significant correlation between leisure and tourism activities. The continuum between leisure and tourism could also have a positive effect on the QOL of the elderly. Leisure and tourism are complicatedly correlated with each other and have joint influences on an individual's QOL. This has important policy implications.

\subsection{Policy Implication: Building Intimacy via Leisure Activities among the Elder}

In both areas, the results supported QOL in leisure life as having positive effects on QOL in intimacy, which implies a key point to elderly life improvements. Elderly people need to use leisure activities to develop intimacy with others. Leisure is not just for fun. It allows elders to communicate with each other and helps maintain their mental health. Community and family activities are the most feasible form of leisure activities for elderly people to be actively involved in. However, living in depopulated areas made this task more difficult; elderly people in depopulated areas have fewer opportunities to take part in social activities than those in populated areas, and if their children live far from them, the only connection they have is their local community and neighbors. That is also one of the reasons why the neighborhood domain contributes more to elderly people's QOL in depopulated areas in our findings. Walker and Hiller [96] found that perceived reciprocal and trusting relationships with neighbors were predictive of life satisfaction and the security of old women living alone. Thus, building a sense of place attachment or community attachment via leisure activities in depopulated areas could become an effective approach to enhancing the QOL of the elderly. Continuing Care Retirement Community (CCRC) has been promoted in America to offer older adults an innovative and independent lifestyle, which creates a new popular senior living model in QOL in leisure and intimacy [97]. Researchers in Japan have in recent years suggested building village hubs to strengthen community connections and promote healthy lifestyles among seniors. Such hubs would provide more chances for elderly people to get social engagements and build connections among nearby villages and enrich the lives of the elderly people. The mental needs of the elderly can be partially solved by participating in leisure activities with others.

How to enhance the sense of well-being of seniors is still a big challenge facing the aging problem all over the world [98]. The Sustainable Development Goals have formally positioned aging health as a global goal and strongly requested the global society to pay more attention to elderly issues.

\section{Conclusions}

The progress of aging societies has brought various challenges to sustainable development all over the world. Although healthy aging is important in achieving the Sustainable Development Goals, relevant studies are very limited. As an additional effort, this study has investigated how leisure and tourism contribute to the elderly's QOL in the domains of leisure and intimacy, in Japan. In particular, this study has compared populated and depopulated areas by collecting valid data from 763 residents from across the whole country. Analyses based on SEM showed that, for both areas, QOL in leisure life had positive effects on QOL in intimacy, while tourism behavior only affects the QOL in populated areas. The above findings suggest that it is more important to provide the elderly with a better leisure environment within their action space than to focus on tourism. Such an environment is useful for improving the intimate relationships of the elderly, which is essential to socially sustainable development in countries like Japan, where the elderly population percentage is very high. 
Despite the above conclusions, it should be noted that our research is not free of limitations. This study only focused on the impact of leisure and tourism on the elderly's QOL in leisure and intimacy. However, QOL is a comprehensive concept consisting of different life domains. The findings can only support how elderly people's leisure and tourism behaviors affect their lives. Other life domains of the elderly should be valued and compared with leisure life domain. For improving the elderly's QOL by involving more stakeholders/sectors, it is necessary to build a more comprehensive research framework based on a holistic view of QOL related to elderly people's lives. Similar research should be further accumulated for deriving more sound insights into effective policymaking, by using more data collected from different countries. In addition, the elderly in depopulated areas are more susceptible to social exclusion. How to improve the QOL of disadvantaged groups is essential for regional development, which needs further studies. Furthermore, it is necessary to examine effects of various policies, e.g., care centers for elders [99], smart technologies for supporting the elderly's life [100], social inclusion policies [101,102], integrated transport and health policy [103], housing policy [104] and land use policy [105] on the improvement of the elderly's QOL.

Author Contributions: Conceptualization, Z.L. and Z.J.; Methodology, Z.L. and Z.J.; Software, Z.J.; Validation, Z.L. and Z.J.; Formal Analysis, Z.L.; Investigation, Z.L. and Z.J.; Resources, Z.J.; Data Curation, Z.J.; Writing-Original Draft Preparation, Z.L.; Writing-Review \& Editing, Z.J.; Visualization, Z.L.; Supervision, Z.J.; Project Administration, Z.J.; Funding Acquisition, Z.J.

Acknowledgments: This research was supported by two scientific projects of Grants-in-Aid for Scientific Research (A), Japan Society for the Promotion of Science (JSPS) (Funding IDs: 15H02271 \& 22246068; Principal researchers: Junyi Zhang).

Conflicts of Interest: The authors declare no conflict of interest.

\section{References}

1. World Population Ageing 2017-The United Nations. Available online: http://www.un.org/ en/development/desa/population/publications/pdf/ageing/WPA2017_Highlights.pdf (accessed on 12 December 2018).

2. The Statistics of Elder Population in Japan, Ministry of Internal Affairs and Communication. Available online: http:/ /www.stat.go.jp/data/topics/pdf/topics103.pdf (accessed on 12 December 2018). (In Japanese)

3. Carella, V.; Monachesi, P. Greener through grey? Boosting sustainable development through a philosophical and social media analysis of ageing. Sustainability 2018, 10, 499. [CrossRef]

4. Zhang, Y.; Li, Y.; Liu, Q.; Li, C. The Built Environment and Walking Activity of the Elderly: An Empirical Analysis in the Zhongshan Metropolitan Area, China. Sustainability 2018, 6, 1076. [CrossRef]

5. Chen, B.; Qiu, Z.; Usio, N.; Nakamura, K. Tourism's impacts on rural livelihood in the sustainability of an aging community in Japan. Sustainability 2018, 10, 2896. [CrossRef]

6. Wada, T.; Ishine, M.; Sakagami, T.; Kita, T.; Okumiya, K.; Mizuno, K.; Rambo, T.A.; Matsubayashi, K. Depression, activities of daily living, and quality of life of community-dwelling elderly in three Asian countries: Indonesia, Vietnam, and Japan. Arch. Gerontol. Geriatr. 2005, 41, 271-280. [CrossRef] [PubMed]

7. Suzuki, M.; Ohyama, N.; Yamada, K.; Kanamori, M. The relationship between fear of falling, activities of daily living and quality of life among elderly individuals. Nurs. Health Sci. 2002, 4, 155-161. [CrossRef]

8. Kikuzawa, S. Multiple roles and mental health in cross-cultural perspective: The elderly in the United States and Japan. J. Health Soc. Behav. 2006, 47, 62-76. [CrossRef]

9. Felce, D.; Perry, J. Quality of life: Its definition and measurement. Res. Dev. Disabil. 1995, 16, 51-74. [CrossRef]

10. Velikova, G.; Booth, L.; Smith, A.B.; Brown, P.M.; Lynch, P.; Brown, J.M.; Selby, P.J. Measuring quality of life in routine oncology practice improves communication and patient well-being: A randomized controlled trial. J. Clin. Oncol. 2004, 22, 714-724. [CrossRef]

11. Zhang, J. (Ed.) Life-Oriented Behavioral Research for Urban Policy; Springer: Tokyo, Japan, 2017.

12. Shoemaker, S. Segmenting the Mature Market: 10 Years Later. J. Travel Res. 2000, 39, 11-26. [CrossRef]

13. Brajša-Žganec, A.; Merkaš, M.; Šverko, I. Quality of life and leisure activities: How do leisure activities contribute to subjective well-being? Soc. Indic. Res. 2011, 102, 81-91. [CrossRef] 
14. Dann, G.M. Senior tourism and quality of life. J. Hosp. Leis. Mark. 2002, 9, 5-19. [CrossRef]

15. Andereck, K.L.; Valentine, K.M.; Vogt, C.A.; Knopf, R.C. A cross-cultural analysis of tourism and quality of life perceptions. J. Sustain. Tour. 2007, 15, 483-502. [CrossRef]

16. Wei, S.; Milman, A. The impact of participation in activities while on vacation on seniors' psychological well-being: A path model application. J. Hosp. Tour. Res. 2002, 26, 175-185. [CrossRef]

17. Kim, H.; Woo, E.; Uysal, M. Tourism experience and quality of life among elderly tourists. Tour. Manag. 2015, 46, 465-476. [CrossRef]

18. Menec, V.H.; Chipperfield, J.G. Remaining active in later life: The role of locus of control in seniors' leisure activity participation, health, and life satisfaction. J. Aging Heal. 1997, 9, 105-125. [CrossRef]

19. Silverstein, M.; Parker, M.G. Leisure activities and quality of life among the oldest old in Sweden. Res. Aging. 2002, 24, 528-547. [CrossRef]

20. Sarvimäki, A.; Stenbock-Hult, B. Quality of life in old age described as a sense of well-being, meaning and value. J. Adv. Nurs. 2000, 32, 1025-1033. [CrossRef]

21. Matanle, P. Introduction: A special focus on shrinking regions. Soc. Sci. Jpn. J. 2010, 13, 183-185. [CrossRef]

22. Gilbert, D.; Abdullah, J. Holidaytaking and the sense of well-being. Ann. Tour. Res. 2004, 31, $103-121$. [CrossRef]

23. Farquhar, M. Elderly people's definitions of quality of life. Soc. Sci. Med. 1995, 41, 1439-1446. [CrossRef]

24. Kaplan, R.M.; Ries, A.L. Quality of life: Concept and definition. J. Chronic Obstruct. Pulm. Dis. 2007, 4, 263-271. [CrossRef] [PubMed]

25. Andereck, K.L.; Nyaupane, G.P. Exploring the nature of tourism and quality of life perceptions among residents. J. Travel Res. 2011, 50, 248-260. [CrossRef]

26. Dalkey, N.; Rourke, D. The Quality of Life Concept; Environmental Protection Agency: Washington, DC, USA, 1973.

27. Scanlon, T. Value, desire, and quality of life. Qual. Life. 1993, 1, 185-201. [CrossRef]

28. Sirgy, M.J. Matherialism and quality of life. Soc. Indic. Res. 1998, 43, 227-260. [CrossRef]

29. Bigelow, D.A.; McFarland, B.H.; Olson, M.M. Quality of life of community mental health program clients: Validating a measure. Community Ment. Health J. 1991, 27, 43-55. [CrossRef] [PubMed]

30. Cummins, R.A. The domains of life satisfaction: An attempt to order chaos. Soc. Indic. Res. 1996, 38, 303-328. [CrossRef]

31. Noll, H.-H. Social indicators and quality of life research: Background, achievements and current trends. Adv. Sociol. Knowl. (VS Verl. Für Sozialwissenschaften, Wiesbaden) 2002, 151-181. [CrossRef]

32. Sirgy, M.J.; Lee, D.J.; Rahtz, D. Research on consumer well-being (CWB): Overview of the field and introduction to the special issue. J. Macromarketing 2007, 27, 341-349. [CrossRef]

33. Costanza, R.; Fisher, B.; Ali, S.; Beer, C.; Bond, L.; Boumans, R.; Danigelis, N.L.; Dickinson, J.; Elliott, C.; Farley, J. An integrative approach to quality of life measurement, research, and policy. Surv. Perspect. Integr. Environ. Soc. 2008, 17-21. [CrossRef]

34. Fernández-Ballesteros, R. Quality of life in old age: Problematic issues. Appl. Res. Qual. Life 2011, 6, 21-40. [CrossRef]

35. Osborne, S.P. The quality dimension. Evaluating quality of service and quality of life in human services. Br. J. Soc. Work 1992, 22, 437-453.

36. Lloyd, K.M.; Auld, C.J. The role of leisure in determining quality of life: Issues of content and measurement. Soc. Indic. Res. 2002, 57, 43-71. [CrossRef]

37. Neal, J.D.; Sirgy, M.J.; Uysal, M. The role of satisfaction with leisure travel/tourism services and experience in satisfaction with leisure life and overall life. J. Bus. Res. 1999, 44, 153-163. [CrossRef]

38. Veenhoven, R. Correlates of Happiness: World Database of Happiness: 7838 [i. E. 7837] Findings from 603 Studies in 69 Nations 1991 [i. E. 1911]-1994. Plan of the Data-Collection: Object; Studies Included, Notation of Findings, Classification of Findings; Erasmus University of Rotterdam: Rotterdam, The Netherlands, 1994.

39. Frank, R.H. The frame of reference as a public good. Econ. J. 1997, 107, 1832-1847. [CrossRef]

40. Oswald, A.J. Happiness and economic performance. Econ. J. 1997, 107, 1815-1831. [CrossRef]

41. Easterlin, R.A. Life cycle welfare: Trends and differences. J. Happiness Stud. 2001, 2, 1-12. [CrossRef]

42. Veenhoven, R. HOW DO WE ASSESS HOW HAPPY WE ARE? Tenets, implications and tenability of three theories. Presented at the Conference on New Direction in the Study of Happiness, Unites States and International Perspectives, University of Notre Dame, Notre Dame, IN, USA, 22-24 October 2006. 
43. Tay, L.; Kuykendall, L.; Diener, E. Satisfaction and happiness-the bright side of quality of life. In Global Handbook of Quality of Life; Springer: Dordrecht, The Netherlands, 2015; pp. 839-853.

44. Zhang, J.; Xiong, Y. Effects of multifaceted consumption on happiness in life: A case study in Japan based on an integrated approach. Int. Rev. Econ. 2015, 62, 143-162. [CrossRef]

45. Ryan, L.; Dziurawiec, S. Materialism and its relationship to life satisfaction. Soc. Indic. Res. 2001, 55, $185-197$. [CrossRef]

46. Sirgy, M.J.; Lee, D.J.; Kressmann, F. A need-based measure of consumer well being (CWB) in relation to personal transportation: Nomological validation. Soc. Indic. Res. 2006, 79, 337-367. [CrossRef]

47. Neal, J.D.; Uysal, M.; Sirgy, M.J. The effect of tourism services on travelers' quality of life. J. Travel Res. 2007, 46, 154-163. [CrossRef]

48. Sirgy, M.J. Toward a quality-of-life theory of leisure travel satisfaction. J. Travel Res. 2010, 49, $246-260$. [CrossRef]

49. Auld, C.J.; Case, A.J. Social exchange processes in leisure and non-leisure settings: A review and exploratory investigation. J. Leis. Res. 1997, 29, 183-200. [CrossRef]

50. Smith, S.L.J.; Godbey, G.C. Leisure, recreation and tourism. Ann. Tour. Res. 1991, 18, 85-100. [CrossRef]

51. Ryan, C. Leisure and tourism-The application of leisure concepts to tourist behavior-A proposed model. In Tourism: The State of the Art; Seaton, A., Ed.; Wiley: Chichester, UK, 1994; pp. 294-307.

52. Page, S.J.; Hall, C.M. The Geography of Tourism and Recreation: Environment, Place and Space; Routledge: London, UK, 2014.

53. Carr, N. The tourism-leisure behavioural continuum. Ann. Tour. Res. 2002, 29, 972-986. [CrossRef]

54. Leung, L.; Lee, P.S. Multiple determinants of life quality: The roles of Internet activities, use of new media, social support, and leisure activities. Telemat. Inform. 2005, 22, 161-180. [CrossRef]

55. Rodríguez, A.; Látková, P.; Sun, Y.Y. The relationship between leisure and life satisfaction: Application of activity and need theory. Soc. Indic. Res. 2008, 86, 163. [CrossRef]

56. Mishra, S. Leisure activities and life satisfaction in old age: A case study of retired government employees living in urban areas. Act. Adapt. Aging 1992, 16, 7-26. [CrossRef]

57. Lennartsson, C.; Silverstein, M. Does engagement with life enhance survival of elderly people in Sweden? The role of social and leisure activities. J. Gerontol. Ser. B Psychol. Sci. Soc. Sci. 2001, 56, S335-S342. [CrossRef]

58. Zimmer, Z.; Lin, H.-S. Leisure activity and well-being among the elderly in Taiwan: Testing hypotheses in an Asian setting. J. Cross-Cult. Gerontol. 1996, 11, 167-186. [CrossRef]

59. Nawijn, J.; Veenhoven, R. The Human Pursuit of Well-Being: The Importance of Holiday Trips. Hum. Purs. Well-Being A Cult. Approach 2011, 39-53.

60. Cecil, A.K.; Fu, Y.; Wang, S.; Avgoustis, S. Cultural tourism and quality of life: Results of a longitudinal study. Eur. J. Tour. Res. 2010, 3, 54-66.

61. Dolnicar, S.; Yanamandram, V.; Cliff, K. The contribution of vacations to quality of life. Ann. Tour. Res. 2012, 39, 59-83. [CrossRef]

62. Uysal, M.; Sirgy, M.J.; Woo, E.; Kim, H.L. Quality of life (QOL) and well-being research in tourism. Tour. Manag. 2016, 53, 244-261. [CrossRef]

63. Jennings, G.; Lee, Y.-S.; Ayling, A.; Lunny, B.; Cater, C.; Ollenburg, C. Quality tourism experiences: Reviews, reflections, research agendas. J. Hosp. Mark. Manag. 2009, 18, 294-310. [CrossRef]

64. Lee, S.H.; Tideswell, C. Understanding attitudes towards leisure travel and the constraints faced by senior Koreans. J. Vacat. Mark. 2005, 11, 249-263. [CrossRef]

65. Arslantas, D.; Ünsal, A.; Metintas, S.; Koc, F.; Arslantas, A. Life quality and daily life activities of elderly people in rural areas, Eskişehir (Turkey). Arch. Gerontol. Geriatr. 2009, 48, 127-131. [CrossRef]

66. Fassino, S.; Leombruni, P.; Abbate Daga, G.; Brustolin, A.; Rovera, G.G.; Fabris, F. Quality of life in dependent older adults living at home. Arch. Gerontol. Geriatr. 2002, 35, 9-20. [CrossRef]

67. Woo, E.; Kim, H.; Uysal, M. A measure of quality of life in elderly tourists. Appl. Res. Qual. Life 2016, 11, 65-82. [CrossRef]

68. Lehto, X.Y.; Jang, S.; Achana, F.T.; O'Leary, J.T. Exploring tourism experience sought: A cohort comparison of baby boomers and the silent generation. J. Vacat. Mark. 2008, 14, 237-252. [CrossRef]

69. Chen, S.C.; Shoemaker, S. Age and cohort effects: The American senior tourism market. Ann. Tour. Res. 2014, 48, 58-75. [CrossRef] 
70. Verghese, J.; Lipton, R.B.; Katz, M.J.; Hall, C.B.; Derby, C.A.; Kuslansky, G.; Ambrose, A.F.; Sliwinski, M.; Buschke, H. Leisure activities and the risk of dementia in the elderly. N. Engl. J. Med. 2003, 348, 2508-2516. [CrossRef] [PubMed]

71. Iwasa, H.; Yoshida, Y.; Kai, I.; Suzuki, T.; Kim, H.; Yoshida, H. Leisure activities and cognitive function in elderly community-dwelling individuals in Japan: A 5-year prospective cohort study. J. Psychosom. Res. 2012, 72, 159-164. [CrossRef] [PubMed]

72. Nakata, M.; Momsen, J. Gender and Tourism: Gender, Age and Mountain Tourism in Japan. In Political Economy of Tourism; Routledge: London, UK, 2010; pp. 151-162.

73. Ryu, E.; Hyun, S.S.; Shim, C. Creating new relationships through tourism: A qualitative analysis of tourist motivations of older individuals in Japan. J. Travel Tour. Mark. 2015, 32, 325-338. [CrossRef]

74. Roberts, J.A.; Clement, A. Materialism and satisfaction with over-all quality of life and eight life domains. Soc. Indic. Res. 2007, 82, 79-92. [CrossRef]

75. Browne, J.P.; O'boyle, C.A.; McGee, H.M.; McDonald, N.J.; Joyce, C.B. Development of a direct weighting procedure for quality of life domains. Qual. Life Res. 1997, 6, 301-309. [CrossRef] [PubMed]

76. Cummins, R.A. Assessing quality of life. Qual. Life People Disabil. Models Res. Pract. 1997, 2, 116-150.

77. Robinson, J.P.; Martin, S. What do happy people do? Soc. Indic. Res. 2008, 89, 565-571. [CrossRef]

78. Rowe, J.W.; Kahn, R.L. Successful aging. Gerontologist 1997, 37, 433-440. [CrossRef]

79. Diener, E.; Emmons, R.; Larsen, J.; Griffin, S. The satisfaction with life scale. J. Pers. Assess. 1985, 49, 71-75. [CrossRef]

80. Kahneman, D.; Krueger, A.B.; Schkade, D.A.; Schwarz, N.; Stone, A.A. A survey method for characterizing daily life experience: The day reconstruction method. Science 2004, 306, 1776-1780. [CrossRef]

81. Jöreskog, K.G.; Sörbom, D. LISREL 8: Structural Equation Modeling with the SIMPLIS Command Language; Scientific Software International: Lincolnwood, IL, USA, 1993.

82. Hooper, D.; Coughlan, J.; Mullen, M.R. Structural equation modelling: Guidelines for determining model fit. Electron. J. Bus. Res. Methods 2008, 61, 53-60. [CrossRef]

83. Iacobucci, D. Structural equations modeling: Fit Indices, sample size, and advanced topics. J. Consum. Psychol. 2010, 20, 90-98. [CrossRef]

84. Reisinger, Y.; Turner, L. Structural equation modeling with Lisrel: Application in tourism. Tour. Manag. 1999, 20,71-88. [CrossRef]

85. Nunkoo, R.; Ramkissoon, H.; Gursoy, D. Use of structural equation modeling in tourism research: Past, present, and future. J. Travel Res. 2013, 52, 759-771. [CrossRef]

86. Vargas-Sánchez, A.; Porras-Bueno, N.; de los Ángeles Plaza-Mejía, M. Explaining residents' attitudes to tourism: Is a universal model possible? Ann. Tour. Res. 2011, 38, 460-480. [CrossRef]

87. Gursoy, D.; State, W. Resident attitudes-A structural modelling approach. Ann. Tour. Res. 2002, 29, 79-205. [CrossRef]

88. Gross, M.J.; Brown, G. An empirical structural model of tourists and places: Progressing involvement and place attachment into tourism. Tour. Manag. 2008, 29, 1141-1151. [CrossRef]

89. Hair Jr, J.F.; Black, W.C.; Babin, B.J.; Anderson, R.E.; Tatham, R.L. SEM: An introduction. In Multivariate Data Analysis: A Global Perspective, 7th ed.; Pearson Education: Upper Saddle River, NJ, USA, 2010; pp. 629-686.

90. Depopulated Areas in Japan, Ministry of Internal Affairs and Communication. Available online: http: / / www.soumu.go.jp/main_content/000542474.pdf (accessed on 12 December 2018). (In Japanese)

91. Wolinsky, F.D.; Stump, T.E.; Clark, D.O. Antecedents and consequences of physical activity and exercise among older adults. Gerontologist 1995, 35, 451-462. [CrossRef]

92. Sabin, E.P. Social relationships and mortality among the elderly. J. Appl. Gerontol. 1993, 12, 44-60. [CrossRef]

93. Iwasaki, Y. Leisure and quality of life in an international and multicultural context: What are major pathways linking leisure to quality of life? Soc. Indic. Res. 2007, 82, 233-264. [CrossRef]

94. Morita, A.; Takano, T.; Nakamura, K.; Kizuki, M.; Seino, K. Contribution of interaction with family, friends and neighbours, and sense of neighbourhood attachment to survival in senior citizens: 5-year follow-up study. Soc. Sci. Med. 2010, 70, 543-549. [CrossRef] [PubMed]

95. Dolnicar, S.; Lazarevski, K.; Yanamandram, V. Quality of life and tourism: A conceptual framework and novel segmentation base. J. Bus. Res. 2013, 66, 724-729. [CrossRef] 
96. Walker, R.B.; Hiller, J.E. Places and health: A qualitative study to explore how older women living alone perceive the social and physical dimensions of their neighbourhoods. Soc. Sci. Med. 2007, 65, 1154-1165. [CrossRef] [PubMed]

97. Zarem, J.E. Today's Continuing Care Retirement Community (CCRC). Available online: http://www. willametteview.org/uploads/documents/Todays_CCRC_LeadingAge.pdf (accessed on 10 November 2018).

98. Nimrod, G. Retirement and tourism Themes in retirees' narratives. Ann. Tour. Res. 2008, 35, 859-878. [CrossRef]

99. Matei, E.; Saghin, D.; Dumitrache, L.; Nae, M. Multidimensional approach on sustainability of ageing in Romanian residential care centres for elders. Sustainability 2018, 10, 3336. [CrossRef]

100. Chung, C.-C.; Lin, C.-L.; Lou, S.-J. Analysis of the learning effectiveness of the STEAM-6E special course-A case study about the creative design of IoT assistant devices for the elderly. Sustainability 2018, 10, 3040. [CrossRef]

101. Ko, D.W.; Bae, Y.H.; Han, J. Social exclusion and switching barriers in Medicare Part D choices. Sustainability 2018, 10, 2419. [CrossRef]

102. Lee, J.; Hong, S.; Park, Y. Predictable surprise: The spatial and social morphology of aging suburbs in the U.S. metropolitan areas. Sustainability 2017, 9, 458. [CrossRef]

103. Li, X.; Zhang, Y.; Du, M. Analysis of travel decision-making for urban elderly healthcare activities under temporal and spatial constraints. Sustainability 2018, 10, 1560. [CrossRef]

104. Feng, I.-M.; Chen, J.-H.; Zhu, B.-W.; Xiong, L. Assessment of and improvement strategies for the housing of healthy elderly: Improving quality of life. Sustainability 2018, 10, 722. [CrossRef]

105. Zhu, B.-W.; Zhang, J.-R.; Tzeng, G.-H.; Huang, S.-L.; Xiong, L. Public open space development for elderly people by using the DANP-V model to establish continuous improvement strategies towards a sustainable and healthy aging society. Sustainability 2017, 9, 420. [CrossRef]

(C) 2018 by the authors. Licensee MDPI, Basel, Switzerland. This article is an open access article distributed under the terms and conditions of the Creative Commons Attribution (CC BY) license (http:/ / creativecommons.org/licenses/by/4.0/). 